\title{
Using the factorial experiment method to analyze the corrosion protection process
}

\author{
Mihail Aurel Țîțu 1,*, Constantin Oprean², Alina Bianca Pop ${ }^{3}$ and Ștefan Țîțu ${ }^{4}$ \\ ${ }^{1}$ Lucian Blaga University of Sibiu, Victoriei Street no. 10, code 550024, Sibiu, România \\ ${ }^{2}$ Lucian Blaga University of Sibiu, Victoriei Street no. 10, code 550024, Sibiu, România \\ ${ }^{3}$ SC TechnoCAD SA, Vasile Alecsandri no. 72, code 430351, Baia Mare, România \\ ${ }^{4}$ Iuliu Hațieganu University of Medicine and Pharmacy, Victor Babeş Street no. 8, code 400012 Cluj- \\ Napoca, România
}

\begin{abstract}
The organization functions are: research-development, production, commercial, financial-accounting, personnel and quality. In this paper the factorial experimental method will be applied, which is currently one of the most widespread methods used in the researchdevelopment departments of the organizations, due to its advantages and efficiency. The experiment was carried out at SC Coifer Impex SRLMirsa's metal structures factory. In this paper it is presented the factors modelling that exerts their influence on two objectives functions: the ensuring the nominal thickness of the rough-cast film and the consumption limiting. For data processing the STATISTICA 7 software was used which provides an accurately and effectively way to determine the influence degree of each variable on the settled objectives.
\end{abstract}

\section{Introduction}

The organization functions are: research - development, production, and commercial, financial - accounting, personnel and quality [1]. Currently, due to their advantages and their efficiency, the factorial experiment method is one of the most widespread methods used in the research and development departments of the organization [2]. The main advantage offered by the factorial experiments is that they are designed and developed according to an optimal strategy [3]. Other important advantages are:

- The use of the factorial experiment method allows to estimate the effect caused by an influence factor on several levels of the other factors, generating conclusions as variables for the entire range of experimental conditions;

- It is more efficient than the classic experiment, and its efficiency increases with the number of variables (influence factors);

- It is absolutely necessary to use this method when the interactions between the influence factors are present, to avoid the erroneous conclusions [4].

The input data to be processed are noted as $\mathrm{x} 1, \mathrm{x} 2, \ldots, \mathrm{xk}$ and they are called - influence factors (independent variables), and the outputs are noted as y1, y2,..., ym and represent

\footnotetext{
${ }^{*}$ Corresponding author: mihail.titu@ulbsibiu.ro
} 
the objective functions (responses) [5]. The factorial experiments are very efficient where the two or more factors influence exist on one or more objective functions [6]. The motivations of the factorial experiment modelling, are: highlighting the influence factors action on the researched system; verifying the hypotheses about internal system interactions; the researched system studying to obtain newer and more complete data; the system optimizing against different criteria [7].

\section{Research method}

The experiment was carried out on SC Coifer Impex SRL - Mirsa, a metal structures factory, and it presents the influence factors modeling of two main objectives:

- Ensuring the nominal thickness of the rough-cast film;

- The consumption limiting.

Ensuring the efficient and durable protection of the metal structures executed in the Coifer Impex factory, is accomplished by observing the operations that compose the technological process of anti-corrosive protection.

The technological process consists of:

- Verifying and preparing the surfaces;

- A good quality equipment and materials use;

- The provided times Keeping in the technical data sheets;

- Depositing / drying layers, re-coating intervals;

- The performing control of this phase.

The product on which the experiment was carried out is a two-component anticorrosion rough-cast based on epoxy resin and EPOMID G3200S-FT zinc phosphate. The nominal film thickness is $50[\mu \mathrm{m}]$ and falls into a theoretical consumption of 160 $\left[\mathrm{g} / \mathrm{m}^{2}\right]$ (no loss).

According to the technical product file of this rough-cast type, in order to obtain the optimal results, the following parameters must be applied:

- Spray application with AIRLESS method;

- Painting pressure: 140 - 160 [atm];

- Dilution: 3 - 5 [\%];

- Nozzle diameter: $0.28-0.53[\mathrm{~mm}]$;

- Spray distance: 250-800 [mm];

- Roughness: 50-75 [ $\mu \mathrm{m}]$.

After the corrosion protection process measurements performing, the following input data were obtained for modeling using the factorial experiment method.

The input data were obtained by results measuring using appropriate devices for each type of the variable. The painting pressure [atm] is measured by means of a pressure-indicator regulator mounted on the used painting equipment. The dilution [\%] represents the proportion of the added solvent to the amount of rough-cast. The nozzle diameter $[\mathrm{mm}]$ represents the hole through the rough-cast is pulverized, with a standard size, guaranteed by the manufacturer. The surface roughness $[\mu \mathrm{m}]$ is measured using a Rugosimeter. The dry film thickness $[\mu \mathrm{m}]$ is measured with Elcometer 456.

The consumption $\left[\mathrm{g} / \mathrm{m}^{2}\right]$ represents the amount of rough-cast used to cover one square meter of rough-cast and it is obtained by dividing the amount of rough-cast used to paint the piece surface. The input data was processed using the statistical software STATISTICA 7, which enables the 2D and 3D graphics realization with a high accuracy and quality. 
Table 1. Input data.

\begin{tabular}{|c|c|c|c|c|c|c|c|}
\hline $\begin{array}{l}\text { Piece } \\
\text { no. }\end{array}$ & $\begin{array}{c}\text { Paint } \\
\text { pressure } \\
\text { [atm] }\end{array}$ & $\begin{array}{c}\text { Dilution } \\
{[\%]}\end{array}$ & $\begin{array}{c}\text { Nozzle } \\
\text { diameter } \\
{[\mathrm{mm}]}\end{array}$ & $\begin{array}{c}\text { Spray } \\
\text { distance } \\
{[\mathrm{mm}]}\end{array}$ & $\begin{array}{c}\text { Roughness } \\
{[\mu \mathrm{m}]}\end{array}$ & $\begin{array}{c}\text { Dry film } \\
\text { thickness } \\
{[\mu \mathrm{m}]}\end{array}$ & $\begin{array}{c}\text { Consumption } \\
{\left[\mathrm{g} / \mathrm{m}^{2}\right]}\end{array}$ \\
\hline & $\mathrm{X1}$ & $\mathrm{X} 2$ & X3 & $\mathrm{X} 4$ & X5 & Y1 & Y2 \\
\hline 1 & 140 & 3 & 0.33 & 390 & 65 & 52.7 & 169.3 \\
\hline 2 & 175 & 1 & 0.53 & 500 & 50 & 73 & 185.6 \\
\hline 3 & 152 & 3.5 & 0.38 & 480 & 65 & 62.3 & 190 \\
\hline 4 & 135 & 5 & 0.38 & 620 & 67 & 46.3 & 179.11 \\
\hline 5 & 140 & 5 & 0.28 & 400 & 65 & 82.3 & 201.5 \\
\hline 6 & 170 & 2 & 0.45 & 320 & 80 & 85.7 & 210 \\
\hline 7 & 170 & 5 & 0.38 & 690 & 73 & 62 & 177 \\
\hline 8 & 135 & 5 & 0.28 & 450 & 65 & 72 & 180 \\
\hline 9 & 110 & 5 & 0.28 & 450 & 80 & 60.5 & 210 \\
\hline 10 & 180 & 2 & 0.53 & 600 & 60 & 59.3 & 185 \\
\hline 11 & 185 & 4 & 0.38 & 450 & 70 & 65.1 & 169.5 \\
\hline 12 & 130 & 5 & 0.28 & 500 & 80 & 55 & 192 \\
\hline 13 & 150 & 4.5 & 0.33 & 400 & 55 & 70.3 & 180 \\
\hline 14 & 150 & 3 & 0.33 & 400 & 65 & 63.5 & 195 \\
\hline 15 & 160 & 4.5 & 0.38 & 390 & 65 & 72.2 & 209 \\
\hline 16 & 155 & 6 & 0.28 & 620 & 60 & 75.3 & 219.5 \\
\hline 17 & 155 & 5.5 & 0.28 & 590 & 65 & 70.4 & 213 \\
\hline 18 & 160 & 3 & 0.53 & 450 & 62 & 73.7 & 220.5 \\
\hline 19 & 110 & 5 & 0.28 & 450 & 50 & 62.5 & 184 \\
\hline 20 & 180 & 5 & 0.45 & 600 & 75 & 58.3 & 201 \\
\hline 21 & 180 & 3 & 0.53 & 450 & 75 & 66 & 185.8 \\
\hline 22 & 150 & 3 & 0.38 & 410 & 65 & 68.4 & 191.2 \\
\hline 23 & 160 & 4.5 & 0.33 & 410 & 55 & 60.5 & 188 \\
\hline 24 & 160 & 2 & 0.53 & 390 & 65 & 70.7 & 224 \\
\hline 25 & 185 & 4 & 0.38 & 450 & 60 & 62.3 & 169.5 \\
\hline 26 & 178 & 1 & 0.45 & 420 & 80 & 68.5 & 192 \\
\hline 27 & 185 & 4 & 0.38 & 380 & 75 & 78.5 & 222.3 \\
\hline 28 & 155 & 4.5 & 0.28 & 585 & 63 & 82.3 & 205.5 \\
\hline 29 & 155 & 2 & 0.53 & 400 & 80 & 59.3 & 196.6 \\
\hline 30 & 160 & 5.5 & 0.28 & 610 & 62 & 80.5 & 218 \\
\hline 31 & 130 & 5 & 0.28 & 400 & 60 & 58.7 & 169 \\
\hline 32 & 180 & 3 & 0.53 & 600 & 65 & 59 & 170 \\
\hline
\end{tabular}




\section{Results and discussions}

After the data processing using STATISTICA 7, the most relevant aspects were graphically presented. First, based on histograms, the experimental data distribution was analysed. So about the variable X1, it was found that the pressure used to apply the rough-cast gets the ranges between 100 [atm] and 190 [atm] - Figure 1. The variable X2 indicates the applied dilution ratio, which was between 0.5 and $6[\%]$, the values are outside the tolerance field Figure 2. The histogram of the X3 influence factor indicates that nozzles with diameters between 0.28 and $0.53[\mathrm{~mm}]$ were used, according to the prescription of the used product Figure 3. The histogram of the X4 influence factor indicates that the distance by the technical prescription of the rough-cast has been respected, i.e. the measured distances ranged from 250-700 [mm] - Figure 4. In the X5 variable situation the histogram indicates that the measured roughness ranges are between 40 and $80[\mu \mathrm{m}]$, it results that are values outside the tolerance range, but most of them are in tolerance - Figure 5. Also, from Y1 histogram we can see that we have values outside the tolerance field, which indicates that we have too thin coat parts that still require a layer coating and also to thick coat parts, parts which lead to a waste of material and energy - Figure 6. The Y2 histogram allows us to notice that the all the pieces painting and the prescribed rough-cast consumption was exceeded and most of the pieces are close to prescribed consumption, i.e. $165\left[\mathrm{~g} / \mathrm{m}^{2}\right]$ Figure 7.

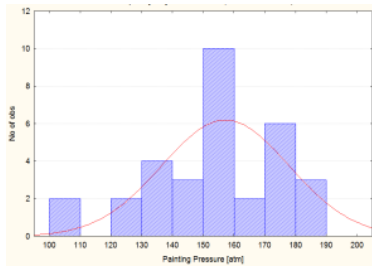

Fig. 1. Painting pressure (X1) histogram.

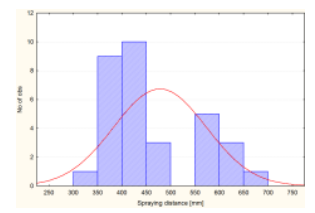

Fig. 4. Spraying distance (X4) histogram.

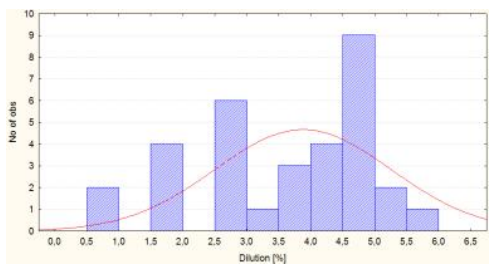

Fig. 2. Dilution (X2) histogram.

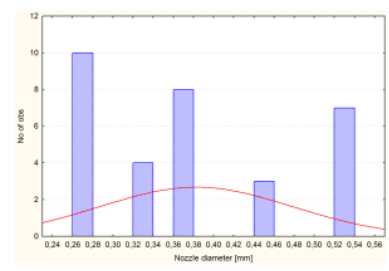

Fig. 3. Nozzle diameter (X3) histogram.

From the presented histograms we can conclude that some values of the measured variables are outside of the tolerance field, so the objective functions are negatively influenced by the studied factors and the researched process results that it is not reliable. 


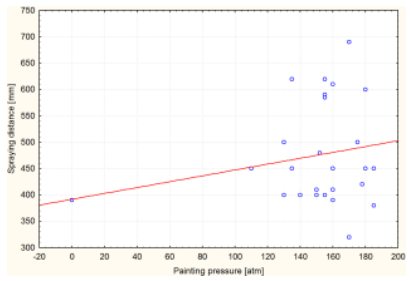

Fig. 8. Dispersion diagram between painting pressure and spraying distance correlation.

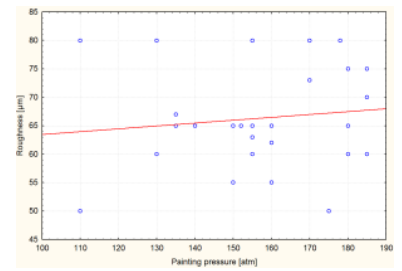

Fig. 9. Dispersion diagram between painting pressure and surface roughness correlation.

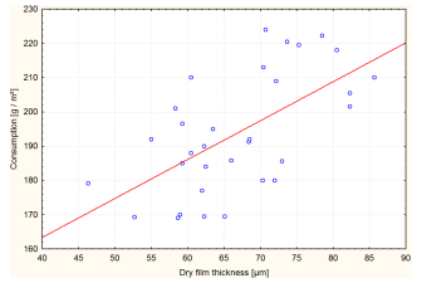

Fig. 10. Dispersion diagram between dry film thickness and rough-cast consumption correlation.

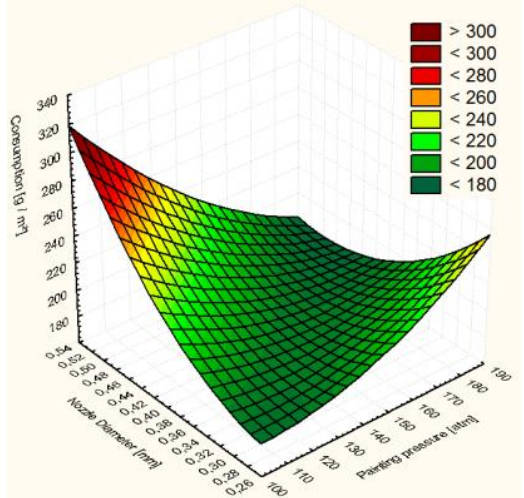

Fig. 11. The consumption 3D variation under the nozzle diameter and painting pressure influence.

Next, the data dispersion was also studied. In this situation it was found that the closest correlations are between painting pressure and spraying distance (Figure 8), between painting pressure and surface roughness (Figure 9) and between dry film thickness and rough-cast consumption (Figure 10).

The other correlations between: nozzle diameter and spray distance, between nozzle diameter and surface roughness, between nozzle diameter and rough-cast film thickness, between nozzle diameter and rough-cast consumption, between surface roughness and layer thickness and between surface roughness and consumption, have a very large dispersion. The Y1 "Layer Thickness" objective function is positively influenced by nozzle diameter increasing, by the spraying distance and the dilution reduction.

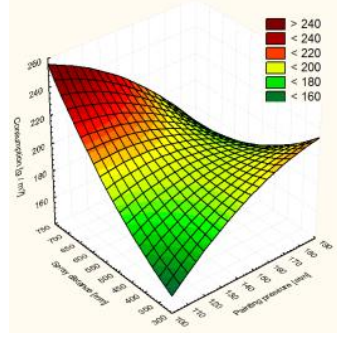

Fig. 12. The consumption 3D variation under the spray distance and painting pressure influence.

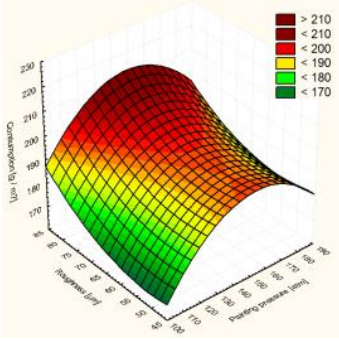

Fig. 13. The consumption 3D variation under the roughness and painting pressure influence.

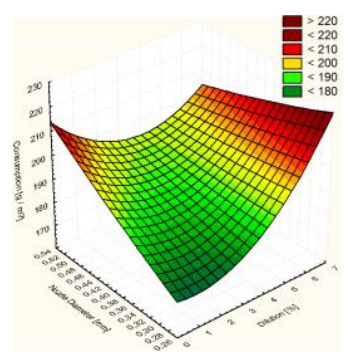

Fig. 14. The consumption $3 \mathrm{D}$ variation under the nozzle diameter and dilution influence. 


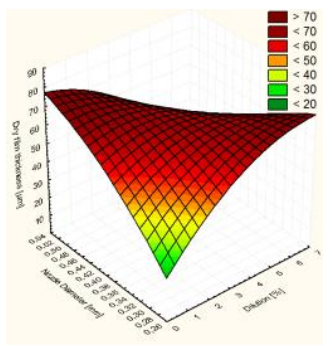

Fig. 15. The dry film thickness $3 \mathrm{D}$ variation under the nozzle diameter and dilution influence.

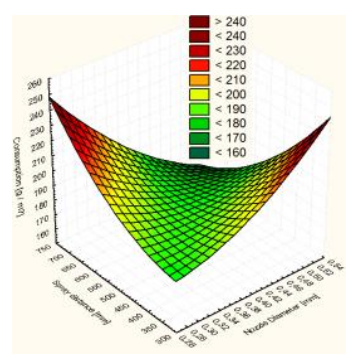

Fig. 18. The consumption 3D variation under the spray distance and nozzle diameter influence.

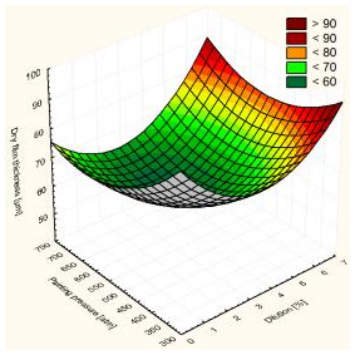

Fig. 16. The dry film thickness $3 \mathrm{D}$ variation under the painting pressure and dilution influence.

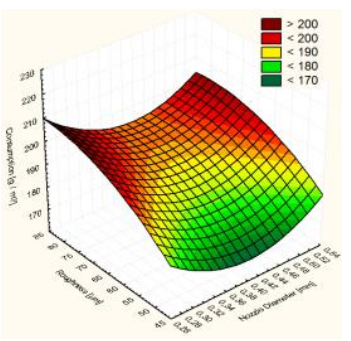

Fig. 19. The consumption 3D variation under the roughness and nozzle diameter influence.

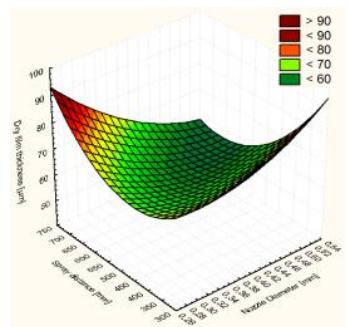

Fig. 17. The dry film thickness 3D variation under the spray distance and nozzle diameter influence.

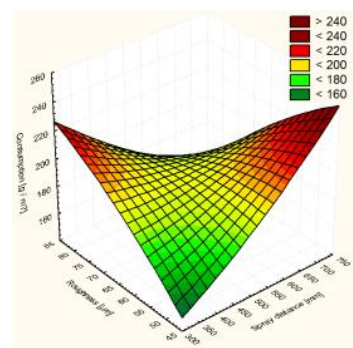

Fig. 20. The consumption 3D variation under the roughness and spray distance influence.

The Y2 objective function represented by rough-cast consumption is negatively influenced by spray distance, painting pressure, nozzle diameter and surface roughness increasing (Figure 11-20).

These observations were made after the three-dimensional (spatial) analysis made on the objective functions in order to track their variation under the influence of controllable factors.

\section{Conclusions}

The used factorial experiment is currently one of the most widespread methods to investigate the purposed research objective, in the form of inputs and outputs.

In this paper some obtained experimentally data (input data) were modelled by the factorial experiment method, and their processing was made using specialized software of statistical data processing, STATISTICA 7.

The experimental researches were aimed to define the most advantageous ways to obtain the protected surface roughness against the corrosive factors by applying the anticorrosive rough-cast by spraying and framing the estimated rough-cast consumption.

The input data are represented by the measurements made on the corrosion protection process of the company where the experiment was conducted and after which we could observe the influence types (negative or positive), as well as the influence degree of certain factors on the objective functions. 
The data processing graphs mated with specialized software allowed to obtain essential information that can be used to optimize the investigated process. It also resulted that the STATISTICA 7 software used, provides a modality that accurately and operable determines the influence degree of each variable on the final values (objectives).

It also emerged that there are possibilities to improve the investigated process by variables controlling, by preparing an optimization plan of the anti-corrosive protection process. The process must be optimized in such a way that it becomes a focused and precise process, in other words - to be a reliable process. In the present paper, it was opportune to use the factorial experiment method of the investigated anticorrosive protective process due to the possibility of the process optimization.

\section{References}

1. A.M. Țîţu, C. Oprean, Managementul calitatii in economia si organizatia bazate pe cunostinte, Editura Agir, Bucuresti, (2008)

2. D. Montgomery, Design and Analysis of Experiments, Eighth Edition ed. Hoboken: John Wiley \& Sons, Inc. (2013)

3. A.M. Țîţu, C. Oprean, Cercetarea experimentală şi prelucrarea datelor, Partea I, Editura Universităţii Lucian Blaga, Sibiu (2006)

4. A.M. Țîţu, C. Oprean, Cercetarea experimentală şi prelucrarea datelor, Partea a II-a, Editura Universităţii Lucian Blaga, Sibiu (2007)

5. A.M. Țîţu, C. Oprean, I. Tomuţă, Cercetarea experimentală şi prelucrarea datelor, Studii de caz, Editura Universităţii Lucian Blaga, Sibiu (2007)

6. T. P. Ryan, J. P. Morgan, Journal of Statistical Theory and Practice 1 (3-4) (2007)

7. M. J. Anderson, P. J. Whitcomb, Kirk-Othmer Encyclopedia of Chemical Technology, DOI: 10.1002/0471238961.0405190908010814.a01.pub3 (2010) 
